\title{
A note on evaluation of wet and dry brewers' grains in concentrate supplements for growing Anglo-Nubian x Fiji local goats in the tropical environment of Samoa
}

\author{
E.M. Aregheore and S. Ting \\ The University of the South Pacific, \\ School of Agriculture, Animal Science Department \\ Alafua Campus Apia, Western Samoa
}

(Received 21 November 2001; revised version 22 July 2002; accepted 11 October 2002)

\section{ABSTRACT}

Six Anglo-Nubian x Fiji local goats between 7-10 months of age, pre-experimental average body weight (BW) of $11.8 \mathrm{~kg}$ were randomly divided into two groups on the basis of body weight. These were used in a change-over experimental design with two 28-days periods, separated by a 7-day adaptation period. Each group of three goats were used to study the potential value of dry or wet brewers' grains in concentrates on feed intake, growth rate, feed efficiency and apparent nutrient digestibility. Dry brewers' grains $(\mathrm{DBG})$ based concentrate had a higher $(\mathrm{P}<0.05) \mathrm{DM}$ content than that of the concentrate based on wet brewers' grains (WBG). The carbohydrate fractions (NDF, ADF and hemicellulose) but not ADL and cellulose were significantly higher $(\mathrm{P}<0.05)$ in the DBG based concentrate than in the WBG concentrate. Non-structural carbohydrate (NSC) was slightly higher in the WBG concentrate than in the DBG based concentrate. Both concentrates had similar gross energy (MJ/kg DM) contents. The forage (Guinea grass) had high moisture content and moderate protein. Concentrate intake was higher $(\mathrm{P}<0.05)$ in the goats on the WBG compared to those on DBG, however forage intake was similar in both groups. Total feed intake (concentrate + forage) was not significantly different $(\mathrm{P}>0.05)$ from each other. Dry matter intakes for $\mathrm{DBG}$ and WBG concentrates were 44 and $45 \mathrm{~g} / \mathrm{kg} \mathrm{BW}^{0.75}$, respectively. Average daily gains were similar in the goats offered either DBG or WBG concentrates. Feed efficiency (feed/gain) was similar in both groups. Protein efficiency and energy efficiency of the goats on either DBG or WBG were 2.6 and 2.9; 4.4 and 4.1, respectively. The digestibility of DM, NDF and GE were significantly higher $(\mathrm{P}<0.05)$ in the goats on DBG based concentrate than those on WBG.

Results of this study suggested that the goats fed either DBG or WBG based concentrates have comparable liveweight gains, feed efficiency and digestibility of $\mathrm{CP}, \mathrm{ADF}, \mathrm{OM}$ and NFE. In conclusion this study has demonstrated that brewers' grains either in the dry or wet form has a potential as feed ingredient in diets for the goats in the tropical environment of Samoa.

KEY WORDS: goats, brewers' grains, DMI, feed utilization, nutrient digestibility, growth 


\section{INTRODUCTION}

In the Pacific island countries (PICs) there are a number of agro-industrial byproducts that are not yet fully integrated into the livestock feeding systems and one of such is the brewers' grains (wet or dry) (Aregheore, 2000). Brewers' grains is an important by-product and the major use of this material has been as a feed for livestock (Preston et al., 1973; Bovolenta et al., 1998).

After drying, the product becomes known as dried brewers' grains (Bovolenta et al., 1998). The concentration of fibre fractions and the low ruminal protein degradability mean that the brewers' grains are preferentially used for feeding ruminants. It is bulky, less palatable and less laxative than wheat bran.

The chemical composition of brewer's grain is influenced by the type and cultivar of cereal grain used in the fermentation process and the efficiency by which starch is converted to alcohol. For instance, wet brewers' grains derived from the fermentation of hard wheat have a higher crude protein $(32 \%)$ than the brewers grain derived from soft wheat (25\%; Wu et al., 1984). Proximate analysis of wet and dry brewers' grains from four PICs (Fiji, Samoa, Tonga and Cook Islands) demonstrated that differences existed in protein and energy contents (Aregheore, 2001 a). Firkins et al. (1984) however reported that wet brewers' grains contained a higher level of acid detergent insoluble protein than dried ones.

Boila and Ingalls (1994) observed that dry brewers' grains increased ruminal undegraded protein in ruminant nutrition. Contrarily, Ojowi et al. (1997) and Mustafa et al. (2000) reported that wet brewers' grains are a relatively poor source of ruminal undegraded protein compared to the dry form. The difference in ruminal undegraded protein content of brewers' grains is due to drying which results in increased levels of acid detergent insolubie protein. However, Firkins et al. (1985) found no significant difference in the ruminal undegraded protcin between wet and dried brewers' grains.

In the PICs, data on growth or digestibility studies with dried brewers' grains (DBG) or wet brewers' grains (WBG) are generally lacking. Information on the utilization of brewers' grains in the nutrition of goats is scant. The objective of this study therefore was to evaluate wet and dry brewers' grains in the concentrate supplements for goats on feed intake, growth rate, feed efficiency and apparent nutrient digestibility in the tropical environment of Apia, Samoa.

\section{MATERIAL AND METHODS}

\section{Location}

The experiment was conducted in the Goat Unit, School of Agriculture, The University of the South Pacific, Alafua Campus, Apia (Samoa) (Latitude $\approx 13.50$ $\mathrm{S}$, Longitude $\approx 172.50 \mathrm{~W}$ ). 
Feed ingredients and preparation of experimental diets

The feed ingredients used were cassava flour, brewers grains (dry or wet), urea $(46 \% \mathrm{~N}), \mathrm{mineral} / \mathrm{vitamin}$ premix and salt. Brewers' grains were collected wet from the Western Samoa breweries Ltd., Apia (Western Samoa). They were spread on an open concrete floor and turned regularly until they were dry. Wet brewers' grains were bagged and kept in a cold room to arrest fermentation. The feedstuffs analysis and composition of concentrates are presented in Tables 1 and 2 .

TABLE 1

Proximate composition of brewers' grains (dry and wet) used for the concentrates and forage (Panicum maximum)*

\begin{tabular}{lrcr}
\hline \multirow{2}{*}{ Nutrients, \% } & \multicolumn{3}{c}{ Feedstuffs } \\
\cline { 2 - 4 } Dry matter, DM & DBG $^{1}$ & WBG $^{2}$ & Forage \\
\hline In dry matter, \% & 98.3 & 33.6 & 22.7 \\
crude protein & & & \\
ether extract & 23.5 & 23.8 & 8.4 \\
ash & 6.2 & 8.5 & 1.5 \\
neutral detergent fibre & 5.6 & 3.0 & 9.4 \\
acid detergent fibre & 41.4 & 36.8 & 28.6 \\
acid detergent lignin & 26.6 & 22.2 & 18.2 \\
hemicellulose & 15.3 & 12.7 & 4.6 \\
cellulose & 14.8 & 14.6 & 10.6 \\
non structural carbohydrate & 11.3 & 9.5 & 4.2 \\
Gross energy, MJ/kg DM & 23.3 & 27.9 & 52.1 \\
\hline
\end{tabular}

* mean of three determinations

'DBG - dry brewers' grains

${ }^{2}$ WBG - wet brewers' grains

TABLE 2

Percentage composition of the experimental concentrates

\begin{tabular}{lcc}
\hline & \multicolumn{2}{c}{ Concentrates } \\
\cline { 2 - 3 } & DBG & WBG \\
\hline Ingredients, \% DM & & \\
dried brewer's grain & 30.0 & - \\
wet brewer's grain & - & 31.0 \\
cassava flour & 66.5 & 65.5 \\
urea & 1.5 & 1.5 \\
minerals and vitamin mix* & 1.5 & 1.5 \\
NaCl & 0.5 & 0.5 \\
Calculated crude protein, \% DM & 13.7 & 13.9 \\
\hline
\end{tabular}

mineral/vitamin mix (Summit multi-mineral salt - Auckland, New Zealand): Supplied the following: Ca 120 g/kg, P 60 g/kg, Mn $600 \mathrm{mg} / \mathrm{kg}, \mathrm{Cu} 150 \mathrm{mg} / \mathrm{kg}$, Co $1.5 \mathrm{mg} / \mathrm{kg}$, I $7.5 \mathrm{mg} / \mathrm{kg}, \mathrm{Fe} 750 \mathrm{~m} / \mathrm{kg}, \mathrm{Zn}$ $600 \mathrm{mg} / \mathrm{kg}$, Se $1.5 \mathrm{mg} / \mathrm{kg}$; vit. A, D and E with copra meal and molasses added 
Animals, experimental design, management and feeding

Six growing crossbred Anglo-Nubian x Fiji local goats between 7-10 months of age and pre-experimental average body weight of $11.8 \mathrm{~kg}$ were divided into two groups of three goats on the basis of body weight. The experiment was a changeover (Gill and Magee, 1976) with two 28-day periods, separated by a 7-day adaptation period. The goats were housed and fed in pens with concrete floors covered with wood shavings for bedding. Prior to the start of the expcriment the pens were cleaned. Also the goats were drenched with Levicare (Ancare, Auckland, New Zealand). The litter material was changed periodically.

The basal diet of Guinea grass (Panicum maximum) was harvested fresh daily and chopped into smaller pieces of $10 \mathrm{~cm}$ before being fed. Four $\mathrm{kg}$ of the Guinea grass was divided into two equal portions and offered at 09.00 and $17.00 \mathrm{~h}$. The concentrate portion for cach treatment group was offered ad libitum. Beforc any feed was offered, the residues were collected and weighed.

The goats had free access to fresh clean water. Body weights were determined on the first three days of each experimental period and the last day of the second period and body weight change was calculated by difference between mean body weights at the beginning and end of each period (von Keyserlingk et al., 1998).

\section{Digestibility studies}

At the end of the growth trial, digestibility study was carried out using the total faecal collection method. The goats received daily $1.50 \mathrm{~kg}$ of each concentrate, fed in two equal portions at 9.00 and $16.00 \mathrm{~h}$. Forage was fed in two equal portions also. Fresh and clean drinking water was provided. Facees were dried in a forced-air oven at $70^{\circ} \mathrm{C}$ for $24 \mathrm{~h}$. Daily dried faeces for each goat over the collection period were bulked, sampled and milled in a hammer mill to pass through a $1.6 \mathrm{~mm}$ sieve and stored in air tight bottles until analysis. The feeds were also processed and stored in air tight bottles until chemical analysis.

\section{Analytical procedures}

AOAC (1995) methods were used to determine nutrient contents of the feeds and faecal samples. All samples were analyzed in triplicates. Dry matter was determined by drying at $102^{\circ} \mathrm{C}$ for $24 \mathrm{~h}$, ash by ashing at $600^{\circ} \mathrm{C}$ for $4 \mathrm{~h}$, crude protein by the micro-Kjeldahl procedure ( $\mathrm{N} \times 6.25)$. Fibre analyses [neutral detergent fibre (NDF) and acid detergent fibre (ADF)] were determined by the procedures of Van Soest et al. (1991). The gross energy (MJ/kg, DM) values of the feeds and faecal samples were determined by adiabatic bomb calorimeter (Parr Instrument Co., Moline, IL), using thermochemical benzoic acid as standard. Feed refusals 
were not analyzed because it was assumed that the composition of feed consumed was the same as that offered.

\section{Statistical analysis}

The data from the feeding trial (voluntary feed intake, growth, feed efficiency and apparent nutrient digestibility) were analyzed using analysis of variance procedures with goat, period and treatment included as mean effects (Gill and Magee, 1976).

\section{RESULTS AND DISCUSSION}

Table 3 presents the proximate chemical composition of the concentrates. The dry brewers' grain $(\mathrm{DBG})$ based concentrates had a higher $(\mathrm{P}<0.05)$ dry matter (DM) content than wet brewers' grain (WBG) based concentrates. The moisture content of the wet brewers' grains was high (Tablel) due to its wet condition, and this contributed to the low DM content of the WBG dict. One reason for the similarities in the $\mathrm{CP}$ content of both wet and dry brewers' grains could be the method used to dry the brewers' grains (sun dried). There could be a difference if excessive heat is applied because this could increase the unavailable protein content of brewers' grains (Van Soest, 1989).

TABLE 3

Chemical composition of experimental concentrates*

\begin{tabular}{lrr}
\hline \multirow{2}{*}{ Nutrients, \% } & \multicolumn{2}{c}{ Dicts } \\
\cline { 2 - 3 } & DBG & WBG $^{1}$ \\
\hline Dry matter (DM) & $88.6^{4}$ & $64.6^{6}$ \\
In dry matter & & \\
crude protein & 14.5 & 14.7 \\
ether extract & 2.8 & 3.2 \\
ash & 5.6 & 5.2 \\
neutral detergent fibre & 19.6 & 18.5 \\
acid detergent fibre & 12.1 & 11.1 \\
acid detergent lignir & 6.5 & 5.8 \\
hemicellulose & 7.3 & 7.4 \\
cellulose & 5.8 & 5.3 \\
non structural carbohydrate & 59.6 & 60.5 \\
Gross energy, MJ/kg DM & 15.3 & 15.5 \\
\hline
\end{tabular}

* mean of three determinations

1,2 explanation see Table 1

i,b) $\mathrm{P}<0.05$ 
The carbohydrate fractions (NDF, ADF and hemicellulose), but not ADL and cellulose, were significantly higher $(\mathrm{P}<0.05)$ in the DBG based concentrate than in the WBG concentrate. However, non-structural carbohydrate (NSC) was slightly higher in the WBG concentrate with 3.2 units higher than the DBG diet. The non-structural carbohydrate contents of DBG and WBG concentrates was calculated using the formula $\mathrm{NSC}=[100-($ ash $+\mathrm{CP}+\mathrm{EE}+\mathrm{NDF})]$. Both concentrates had similar gross energy $(\mathrm{MJ} / \mathrm{kg} \mathrm{DM})$ contents not different from value reported by Preston et al. (1973).

The Guinea grass had high moisture content and moderate protein and these nutrients reflected on the stage of growth at which the grass was harvested for feeding. Carbohydrate fractions were also moderate for a five-week re-growth Guinea grass. The CP content and energy value obtained are close to the values carlier reported for Guinea grass during the rainy season in Samoa (Aregheore, $200 \mathrm{lb}$ ).

Voluntary feed intake, liveweight gain, feed efficiency and performance of the goats are presented in Table 4. By-product such as brewers' grains either in dry or wet forms is incorporated into livestock diets to set energy and protein level consistent with targeted performance levels for growing or finishing animals. Feed intake was higher $(\mathrm{P}<0.05)$ in the goats that received the WBG based concentrate compared to those on the DBG concentrate. The two concentrates had similar energy values, however, the DBG based concentrate had more fibre fractions. The higher DM content of the DBG could be responsible for the low feed intake. Mustafa et al. (2000) opined that the higher the DM contents of thin stillage the greater the reduction in feed intake.

TABLE 4 Feed intake, growth rate and feed efficiency of goats on dry and wet brewers' grains concentrate supplements*

\begin{tabular}{llcc}
\hline \multirow{2}{*}{ ltems } & \multicolumn{3}{c}{ Concentrates } \\
\cline { 2 - 4 } & DBG & WBG & \pm SEM \\
\hline Intake, $\mathrm{kg} / \mathrm{DM} / \mathrm{d}$ & & & \\
$\quad$ concentrate & $0.242^{\mathrm{b}}$ & $0.343^{\mathrm{u}}$ & 0.05 \\
$\quad$ forage & 0.99 & 1.02 & 0.01 \\
$\quad$ total & 1.23 & 1.36 & 0.07 \\
Liveweight, $\mathrm{kg}$ & & & \\
$\quad$ initial & 11.8 & 11.8 & 0.00 \\
$\quad$ final & 14.3 & 14.4 & 0.05 \\
Daily liveweight gain, g/day & 45 & 46 & 0.50 \\
Total dry matter intake, g/kg Wo.7s & 44 & 45 & 0.50 \\
Feed efficiency, feed/gain & 2.7 & 2.9 & 0.10 \\
Protein efficiency, protein intake/weight gain, g & 2.6 & 2.9 & 0.15 \\
ME efficiency, ME MJ intake/weight gain, g & 4.4 & 4.1 & 0.15 \\
\hline
\end{tabular}

* mean of six goats

1.2 explanation see Table 1

a,b $\mathrm{P}<0.05$ 
In the dry form it occupies large volume in the rumen thereby limiting gut capacity, whereas the presence of moisture in the WBG could have caused cellulose to swell, increasing its availability for microbial attack. It should be noted that the rate of breakdown of a diet determines its potential intake and utilization. Another reason for the low concentrate intake of the goats on the DBG diet could be due to the low palatability of brewers' grains in the dry form (Ensminger et al., 1990). Firkins et al. (1985) also reported that dry maize gluten feed (DCGF) was less palatable than wet maize gluten feed (WCGF). Comparatively the intake of the goats on WBG based concentrate was higher than those of the goats on DBG diet. In this trial there was no incidence of diarrhoea in goats on WBG diet and this agreed with Firkins et al. (1985) who did not observe diarrhoea when WCGF was feed.

Both DBG and WBG are relatively good sources of supplemental protein and encrgy for growing animals. Armentano et al. $(1983,1986)$ and Polan et al. (1985) reported that DBG are excellent protein source for lactating cows and also contain protein resistant to rumen degradation. Ojowi et al. (1997) on the other hand reported that WBG would not be considered as a good source of rumen degradable protein. However, Firkins et al. (1984) found no significant differenee between wet and dry maize distillers' grains in protein utilization.

Forage intake was similar in both groups. Total feed intake (concentrate + forage) was not significantly different $(\mathrm{P}>0.05)$ from each other. Daily dry matter intakes (DMI, $\mathrm{g} / \mathrm{kg} \mathrm{BW}{ }^{0.75}$ ) were 44 and 45 for DBG and WBG based concentrates, respectively.

Daily liveweight gains were similar in the goats offered concentrate dicts based on either DBG or WBG and were relatively low compared to the values obtained by Kumar (2000) for goats of the same age and breed. The concentrates cannot be implicated for the low liveweight gains because they met the nutrient requirements for protein and energy suggested by Kumar (2000) as adequate for that breed and age group of goats in the tropical environment of Samoa. The levels of brewers' grains used in this trial are not as high as those reported by Bovolenta et al. (1998) for growing lambs, yet they obtained better liveweight gains in lambs. Better liveweight gains have been reported in other trials for goats of the same breed and age as used in this trials (Ash ct al., 1992; Aregheore and Cawa, 2000) in the tropical environment of Samoa. The short experimental period may be implicated for the low liveweight gain obtained in this trial and not necessary the concentrates.

Feed cfficiency (feed/gain) was similar in both groups. Protein efficiency values for the DBG and WBG fed goats were 2.6 and 2.9, respectively, while ME efficiency 4.4 and $4.1 \mathrm{MJ} / \mathrm{kg}$, respectively. The similarity in protein efficiency of the goats fed either DBG or WBG based diets in this trial contradicts the report of Ham et al. (1994) who observed differences in protein efficiency between cows fed wet distiller grains (WDG) and dry distillers grains plus solubles (DDGS). They observed that cattle fed WDG had numerically higher protein efficiency values than those fed DDGS, but the differences were not significant. 
The digestibility (Table 5) of DM, NDF and GE were significantly higher $(\mathrm{P}<0.05)$ in the goats on the DBG based diet than in those on WBG. In this trial it was observed that the goats tended to digest more NDF of the DBG based concentrate than did those on WBG. The digestibility of other nutrients such as CP, $\mathrm{ADF}, \mathrm{OM}$ and NFE were similar in both groups. In this trial total fibre digestibility for DBG and WBG concentrates was relatively high and this could be due to their high hull content. The DM content of the concentrates may be implicated for differences observed in DM digestibility by the goats. The improved digestibility of GE obtained in the goats that were fed the DBG based concentrate could be due to its retention time in the rumen. The longer a diet stays in the rumen, the more rumen microbes have to digest it (Olatunji ct al., 1976).

TABLE 5

Apparent nutrient digestibility coefficients in goats offered wet and dry brewers' grains based concentrates*

\begin{tabular}{llcc}
\hline \multirow{2}{*}{ Nutrients, \% } & \multicolumn{3}{c}{ Concentrates } \\
\cline { 2 - 4 } & $\mathrm{DBG}^{\mathrm{1}}$ & $\mathrm{WBG}^{2}$ & \pm SEM \\
\hline Dry matter & $69.2^{\mathrm{a}}$ & $64.4^{\mathrm{b}}$ & 7.40 \\
Organic matter & 70.2 & 70.9 & 0.32 \\
Crude protein & 77.8 & 76.9 & 0.45 \\
Neutral detergent fibre & $68.4^{\star}$ & $65.2^{\mathrm{b}}$ & 1.60 \\
Acid detergent fibre & 61.0 & 60.8 & 0.10 \\
Nitrogen free extractives & 68.3 & 68.1 & 0.10 \\
Energy & $66.2^{\circ}$ & $62.3^{\mathrm{b}}$ & 1.95 \\
Digestible energy, g/kg DM & 91 & 90 & 0.50 \\
\hline
\end{tabular}

* mean of six goats

1.2 explanation see Table 1

u,b $\mathrm{P}<0.05$

Apparent digestibilities of CP by the goats fed DBG or WBG based concentrates were similar ( 77.8 and $76.9 \%$, respectively; Table 5). This observation concurred with the early report of Firkins et al. (1985) for wet and dry distillers' grains who did not find any significant difference in apparent $\mathrm{N}$ digestibility by lambs fed DWG or DDG. Nakamura et al. (1994) did not find any difference in protein digestibility between distillers' samples.

If wet grains are to be used in commercial feeding of ruminant animals onc needs the availability of cold room storing facilities and this could pose as a problem that may militate against its large usage in the wet form. Also, if drying would be carricd out manually as was done in this trial it would be a time consuming and expensive operation to dry the wet grains for commercial use. However, results from this study suggested that the goats fed either DBG or WBG have comparable liveweight gains, feed efficiency and digestibility of $\mathrm{CP}, \mathrm{ADF}, \mathrm{OM}$ and NFE. The significant differences obtained between the goats in the intakes of concentrate portions was 
due to the forms of brewers' grains used, however, total voluntary feed intakes (concentrate + forage) were similar. This was reflected in the voluntary dry matter intake of 44 and $45 \mathrm{~g} / \mathrm{kg} \mathrm{BW}^{0.75}$ for the goats on DBG or WBG concentrates, respectively.

Liveweight gains reported in this trial should be taken as indicators but not necessarily the level of animal performance these concentrates might support because of the change-over principles - short period. In both the dry or wet forms, brewers' grains secms equally suitable for feeding goats allowing considerable flexibility in approaches to management and feeding.

In conclusion this study has demonstrated that brewers' grains either in the dry or wet form is a potential feed ingredient in the concentrate of the goats in the tropical environment of Samoa.

\section{ACKNOWLEDGEMENT}

EMA is grateful to Mr. Umar Mohammed, the Director of IRETA (Institute for Research, Extension and Training in Agriculture), School of Agriculture, The University of the South Pacific, Alafua Campus, Apia (Samoa) for the partial funding of this project, and also to Mr. Daya Perera for the initial laboratory analyses.

\section{REFERENCES}

$\Lambda \mathrm{O} \Lambda \mathrm{C}, 1995$. Official Methods of Analysis, Association of Official Analytical Chemist. 16th Edition. Washington, DC

Aregheore E.M., 2000. Crop residues and agro-industrial by products in four Pacific Island countries: Availability, utilization and potential value in ruminant nutrition. Asian-Austr. J. Anim. Sci. 13, Suppl. B, 266-269

Aregheore E.M., 2001a. Traditional Staple Foods and Some Feedstuffs of the Pacific Islands: their Chemistry, Biochemistry and Nutrient Composition. IRETA Print Media Unit, IRETA, USP, Alafua Campus, $\Lambda$ pia (Samoa), pp. 65

Aregheore E.M., 200 lb. Nutritive valuc and utilization of three grass species by crossbred Anglo-Nubia goats in Samoa. Asian-Austr. J. Anim. Sci. 14, 1389-1393

Aregheore E.M., Cawa K., 2000. Voluntary intake by crossbred Anglo-Nubian goats of water hyacinth (Eichhornia crassipes) fed in two states plus guinea grass (Panicum maximum) in confinement. Sci. Agr. Bohemica 31 (4), 261-271

Armentano L.E., Herrington 'T. ., Polan C.E., 1983. Ruminal degradation of dried brewers' grain, wet brewers' grains and soybean meal in situ and in vivo. J. Dairy Sci. 66, Suppl. 1, 171 (Abstr.)

Armentano L.E., Herrington T.A., Polan C.E., Moe, A.J., Herbein J.H, Umstadt P., 1986. Ruminal degradation of dried brewers' grain, wet brewers' grains and soybean meal. J. Dairy Sci. 69, 2124-2133

Ash A.J., Solomona L., Waroka W.T., 1992. Effectiveness of low-cost protein supplements for goats in the South Pacific. J. South Pacific Agr. 1(3), 55-58 
Biola R.J., Ingalls R.J., 1994. The ruminal degradation of dry matter, nitrogen and amino acids in wheat-based distillers' grains in sacco. Anim. Feed Sci. Tech. 48, 57-72

Bovolenta S., Priasentier E., Peresson C., Malossini F., 1998. The utilization of diets containing increasing levels of dried brewers' grains by growing lambs. Anim. Sci. 66, 689-695

Ensminger M.E., Oldfield J.E., Heineman W.W., 1990. Feeds and Nutrition. 2nd Edition. The Ensminger Publishing Company, Clovis, California

Firkins J.L., Berger L.L., Fahey G.C., 1985. Evaluation of wet and dry distillers grains and wet and dry corn gluten feeds for ruminants. J. Anim. Sci, 60 , 847-860

Firkins J.L., Berger L.L., Fahey G.C., Merchen N.R., 1984. Ruminal nitrogen degradability and escape of wet and dry distillers' grains and dry gluten feeds. J. Dairy Sci. 67, 1936-1944

Fisher D.J., McKinnon J.J., Mustafa A.F., Christensen D.A, McCartney D., 1999. Evaluation of wheat based thin stillage as a water source for growing and finishing cattle. J. Anim. Sci. 77, 2810-2816

Gill J.L., Magee W.I., 1976. Balanced two-periods change over designs for several treatments. J. Anim. Sci. 42, 775-777

Ham G.A., Stock R.A., Klopfenstein T.J., Larson M.E., Shain D.H., Huffman R.P., 1994. Wet corn distillers byproducts compared with dried corn distillers grains with solubles as a source of protein and energy for ruminants. J. Anim. Sci. 72, 3246-3257

Kumar A., 2000. Energy and Protein Requirements of Crossbred Anglo-Nubian Goats in Samoa. B. Agr. Special Project. The University of the South Pacific, School of Agriculture, Apia (Samoa), pp. 26

Mustafa A.F., McKinnon J.J., Ingledew M.W., Christensen D.A., 2000. The nutritive value for ruminants of thin stillage and distillers grains derived from wheat, rye, triticale and barley. J. Sci. Food Agr. 80, 607-613

Nakamura T., Klopfenstein T.J., Britton R.A., 1994. Evaluation of acid detergent insoluble nitrogen as an indicator of protein quality in nonforage proteins. J. Anim. Sci. 72, 1043-1048

Olatunji O., Mba A.U., Olubajo F.O., 1976. Dietary effects on digestibilities of protein, carbohydrate component and metabolizable energy values for West African Dwarf sheep. East Afr. Agr. Forest. J. 42 (1), 76-88

Ojowi M.O., McKinnon J.J., Mustafa A.F., Christensen D.A., 1997. Evaluation of wheat-based wet distiller's grains for feedlot cattle. Can. J. Anim. Sci. 77, 447-454

Preston R.L., Vance R.D., Cahill V.R., 1973. Energy evaluation of brewers' grains for growing and finishing cattle. J. Anim. Sci. 37, 174-178

Polan C.E., Herrington T.A., Wark W.A., Armentano L.E., 1985. Milk production response to diets supplemented with dried brewers' grain, wet brewers' grains or soybean meal. J. Dairy Sci. 69, 2124-2133

Van Soest P.J., 1989. On the digestibility of bound N in distillers'grains: Re-analysis. Proceedings of Cornell Nutrition Conference, Syracuse, NY, pp. 185-199

Van Soest P.J., Robertson J.B., Lewis B.A., 1991. Methods for dietary fiber, neutral detergent fiber and non-starch polysaccharides in relation to animal nutrition. J. Dairy Sci. 74, 3583-3597

Von Keyserlingk M.A.G., Gardner W.C., Fisher L.J., Shelford J.A., 1998. A comparison of textured versus pelleted concentrates on rumen degradability, dry matter intake, milk yield and composition in lactating Holstein cow. Can. J. Anim. Sci. 78, 219-224

Wu Y.V., Sexson K.R., Lagoda A.A., 1984. Protein-rich residue from wheat alcohol distillation: Fractionation and characterization. Cereal Chem. 61, 423-427 


\section{STRESZCZENIE}

Ocena wartości pokarmowej świeżego i suszonego młóta jako składnika mieszanki treściwej w żywieniu rosnących anglo-nubijskich $x$ Fiji miejscowych kóz w tropikalnych warunkach Samoa

Sześć anglo-nubijskich x Fiji miejscowych kóz w wieku 7-10 miesięcy i początkowej masie ciała (m.c.) $11,8 \mathrm{~kg}$, podzielono na 2 grupy na podstawie masy ciała. Zastosowano przemienny układ doświadczalny z dwoma 28-dniowymi okresami, podzielonymi 7-dniowym okresem adaptacyjnym. Badano wpływ skarmiania suszonego (DBG) lub świeżego (WBG) młóta, stanowiących składnik mieszanek treściwych, na pobranie paszy, przyrosty, wykorzystanie paszy oraz strawność składników pokarmowych. Zawartość s.m. w paszy treściwej z DBG była większa niż WBG (88,6 vs 64,6\%; $\mathrm{P}<0,05)$, podobnie jak zawartość frakcji węglowodanów: NDF, ADF $\mathrm{i}$ hemicelulozy $(\mathrm{P}<0,05)$, lecz nie ADL i celulozy. Zawartość węglowodanów niestrukturalnych (NSC) była nieco większa w paszy treściwej z WBG niż z DBG. Zawartość energii (MJ/kg s.m.) była podobna w obydwóch rodzajach paszy treściwej. Paszę objętościową stanowiło proso olbrzymie, o niskiej zawartości s.m. $(22,7 \%)$ i umiarkowanej białka ( $8,4 \%$ w s.m.).

Kozy zjadały więcej $(\mathrm{P}<0,05)$ paszy treściwej zawierającej WBG niż DBG, przy podobnym pobraniu paszy objętościowej. Pobranie s.m. paszy treściwej z DBG i WBG wynosiło 44 i $45 \mathrm{~g} / \mathrm{kg}$ m.c. ${ }^{0.75}$, odpowiednio. Średnie dzienne przyrosty kóz obydwóch grup i wykorzystanie paszy były podobne. Wykorzystanie białka i energii przez kozy otrzymujące DBG lub WBG wynosiło odpowiednio 2,6 i 2,9 oraz 4,4 i 4,1. Strawność s.m., NDF i energii brutto dawek z DBG była istotnie lepsza $(\mathrm{P}<0,05)$ niż dawek $\mathrm{z}$ WBG. 